\title{
Temperature Characteristics of Psychrotrophic and Psychrophilic Bacteria
}

\author{
By WOLFGANG REICHARDT AND RICHARD Y. MORITA* \\ Department of Microbiology, and School of Oceanography, Oregon State University, \\ Corvallis, Oregon 97331, U.S.A.
}

(Received 18 June 1981)

\begin{abstract}
When the Arrhenius equation is applied to microbial growth rates, a temperature characteristic $\left(\mu_{\mathrm{A}}\right)$ represents the activation energy. While these $\mu_{\mathrm{A}}$ values describe the energetics favouring growth, there is still no convincing evidence from empirical data to support the idea of a widely applicable relationship between $\mu_{\mathrm{A}}$ values and optimal growth temperatures, which may serve as a basis for the classification of psychrophiles, psychrotrophs, mesophiles and thermophiles. The $\mu_{\mathrm{A}}$ values for the exponential growth rates of 16 psychrophilic and psychrotrophic bacterial strains, including 9 from the literature, varied from 3 to $33\left(\mathrm{kcal} \mathrm{mol}^{-1}\right)$. A plot of $\mu_{\mathrm{A}}$ versus growth temperature optimum deviated considerably from empirical equations reported recently (Mohr \& Krawiec, 1980) for a different selection of strains. Moreover, Arrhenius profiles with two distinct slopes at suboptimal temperatures were not restricted to bacteria with growth temperature optima higher than $37^{\circ} \mathrm{C}$, as had been suggested in that report. A psychrotrophic strain of Cytophaga johnsonae with a growth temperature optimum of $23-25^{\circ} \mathrm{C}$ was characterized by two different temperature characteristics. Furthermore, in the upper range of suboptimal temperatures $\left(11-24^{\circ} \mathrm{C}\right)$, temperature characteristics $\left(\mu_{\mathrm{A} 1}\right)$ were also affected by temperature acclimation of the inoculum.
\end{abstract}

\section{INTRODUCTION}

Growth-temperature relationships of bacteria are adequately described by temperature characteristics representing Arrhenius constants $\left(\mu_{A}\right)$ of the exponential growth rates (Arrhenius, 1908; Dean \& Hinshelwood, 1966). However, some attempts to establish a relationship between $\mu_{\mathrm{A}}$ and the temperature ranges used for the classification of psychrophiles, psychrotrophs, mesophiles and thermophiles (Ingraham, 1958) could not be confirmed (Shaw, 1967; Hanus \& Morita, 1968; Tai \& Jackson, 1969). Nevertheless, a relationship between $\mu_{\mathrm{A}}$ and growth temperature optima has recently been described on the basis of two empirical equations (Mohr \& Krawiec, 1980), suggesting a distinctive pattern for bacteria with growth temperature optima below $15^{\circ} \mathrm{C}$ and $30^{\circ} \mathrm{C}$, i.e. psychrophiles and psychrotrophs, respectively (Morita, 1975). Our data, obtained from a set of psychrophilic and psychrotrophic freshwater isolates, do not confirm the general validity of those equations nor is there substantial published evidence for their assumption.

Mohr \& Krawiec (1980) described the occurrence of complex Arrhenius profiles consisting of more than one negative slope. They suggested that only organisms with optimum growth temperatures above approximately $37^{\circ} \mathrm{C}$ can have two distinct temperature characteristics at suboptimum temperatures. In contrast to this suggestion, we show here that disparate Arrhenius profiles can also occur in psychrotrophic bacteria with growth temperature optima far below $37^{\circ} \mathrm{C}$. 


\section{METHODS}

Seven psychrophilic and psychrotrophic isolates from cold $\left(<5^{\circ} \mathrm{C}\right)$ freshwater environments were grown at 6 , $10,14,18,22,26$ and $30^{\circ} \mathrm{C}$ (shaking water bath, operated at $150 \mathrm{rev}$. $\mathrm{min}^{-1}$ ) in $50 \mathrm{ml}$ Erlenmeyer flasks containing $10 \mathrm{ml}$ half-strength Difco nutrient broth. Growth rates were calculated from readings, taken at $12 \mathrm{~h}$ intervals, of apparent absorbance at $578 \mathrm{~nm}(0.2 \mathrm{ml}$ microcuvette, $1 \mathrm{~cm}$ path-length).

A psychrotrophic strain of Cytophaga johnsonae (strain C21) had been isolated from lake water (Reichardt, 1974). Its exponential growth rates were determined in a shaking (40 strokes $\mathrm{min}^{-1}$ ) Temperature Gradient Incubator (Scientific Industries Inc., Mineola, N.J., U.S.A.) constructed for duplicate incubation in side-arm tubes. These contained $10 \mathrm{ml}$ of autoclaved basal mineral medium [containing $\left(\mathrm{g}^{-1}\right):\left(\mathrm{NH}_{4}\right)_{2} \mathrm{SO}_{4}, 1 ; \mathrm{MgSO}_{4} .7 \mathrm{H}_{2} \mathrm{O}, 0 \cdot 2$; $\mathrm{CaCl}_{2}, 0.003 ; \mathrm{FeCl}_{3}, 0.0003$; together with $10 \mathrm{mM}-\mathrm{KH}_{2} \mathrm{PO}_{4} / \mathrm{Na}_{2} \mathrm{HPO}_{4}$ buffer, $\mathrm{pH} 7.0$ ] supplemented with $10 \mathrm{~mm}$ filter-sterilized $N$-acetylglucosamine as sole organic carbon and nitrogen source. Tubes were inoculated with $0 \cdot 1$ $\mathrm{ml}$ portions of late-exponential phase cultures grown at 10 or $23{ }^{\circ} \mathrm{C}$ (apparent absorbance at $500 \mathrm{~nm}$ of 0.5 ; Bausch \& Lomb Spectronic 20). Growth of cultures was monitored at 3-8 h intervals for up to $72 \mathrm{~h}$ using the same instrument. From semi-logarithmic plots of apparent absorbance, the exponential growth rates $(k)$ were determined using the equation: $k=\ln \left(A_{\mathrm{n}} / A_{0}\right) / \Delta t$, in which $A_{0}$ and $A_{\mathrm{n}}$ are the apparent absorbances at the beginning and end, respectively, of the time interval $\Delta t$.

To calculate temperature characteristics, a specific version of the Arrhenius equation applicable to microbial growth rates (Dean \& Hinshelwood, 1966) was employed, i.e. $k=A \mathrm{e}^{-\mu_{A} / R T}$, in which $\mu_{\mathrm{A}}$, the temperature characteristic, is here substituted for the activation energy, $R$ is the gas constant $\left(1.987 \mathrm{cal} \mathrm{K}^{-1} \mathrm{~mol}^{-1}\right), T$ is the absolute temperature (K), and $A$ is a constant. In Arrhenius plots showing $\ln k\left(\mathrm{~h}^{-1}\right)$ as a function of $1 / T\left(\mathrm{~K}^{-1}\right)$, the negative slopes of the linear portions of the curves obtained at suboptimal growth temperatures equalled $-\mu_{\mathbf{A}} / \boldsymbol{R}$, with $r^{2}$ values describing their goodness of fit.

\section{RESULTS AND DISCUSSION}

Temperature characteristics have generally been given the units $\mathrm{kcal} \mathrm{mol}^{-1}$. However, SI guidelines require the use of the joule $(1 \mathrm{cal}=4.184 \mathrm{~J})$, and the meaning of the molar dimension in connection with bacterial growth is obscure. Hence, we suggest calculating Arrhenius constants in $\mathrm{kcal} \mathrm{mol}^{-1}$ but without expressing the units, until a meaningful alternative is found. This is in agreement with the original description of $\mu_{\mathbf{A}}$ (Arrhenius, 1908) and a few later publications (Hanus \& Morita, 1968; Baker, 1974).

\section{General validity of the Mohr-Krawiec equations}

In order to check the general applicability of the empirical relationship between temperature characteristics $\left(\mu_{A}\right)$ and growth temperature optima of Mohr \& Krawiec (1980), $\mu_{A}$ values of seven of our isolates and nine from the literature were plotted against growth temperature optima up to $30^{\circ} \mathrm{C}$ (Fig. 1). The $\mu_{\mathrm{A}}$ values of these psychrophilic and psychrotrophic bacteria varied over a relatively wide range, from 3 to 33 . The empirical curve obtained by Mohr \& Krawiec (1980) for a corresponding range of growth temperature optima, i.e. $\leqslant 30^{\circ} \mathrm{C}$, was described by the equation: $\mu_{1}=\left(2.73 \times 10^{5}\right) t^{-0.738}$, with $\mu_{1}$ corresponding to our $\mu_{\mathrm{A} 1}$. This equation was based on $\mu_{1}$ values ranging from 12.7 to 51.9 , and suggested a very steep increase of the temperature characteristic in the lower range of the growth temperature optima, i.e. below $25^{\circ} \mathrm{C}$. The steepness was caused exclusively by two psychrophiles with extremely high $\mu_{1}$ values (51.9 and 39.0). However, when considering the $\mu_{\mathrm{A}}$ versus temperature optimum plot obtained for a larger number of psychrophilic and psychrotrophic bacteria (Fig. 1), it seems unlikely that the $\mu_{\mathrm{A}}$ values on which the empirical equation of Mohr \& Krawiec (1980) was based, were characteristic of the majority of bacteria with low temperature optima. The temperature characteristics of most of our psychrophilic and psychrotrophic isolates and those based on literature values for other bacteria of these groups were considerably lower. Moreover, the Arrhenius constants of the two Vibrio marinus strains used in the empirical curve of Mohr \& Krawiec (1980) (39.0 and 23.2) were much higher than those reported in an earlier paper $(16.2$ and 16.4 , respectively; Hanus \& Morita, 1968). Thus, the empirical equations presented by Mohr \& Krawiec (1980) are not applicable to other psychrophilic and psychrotrophic bacteria nor are they 


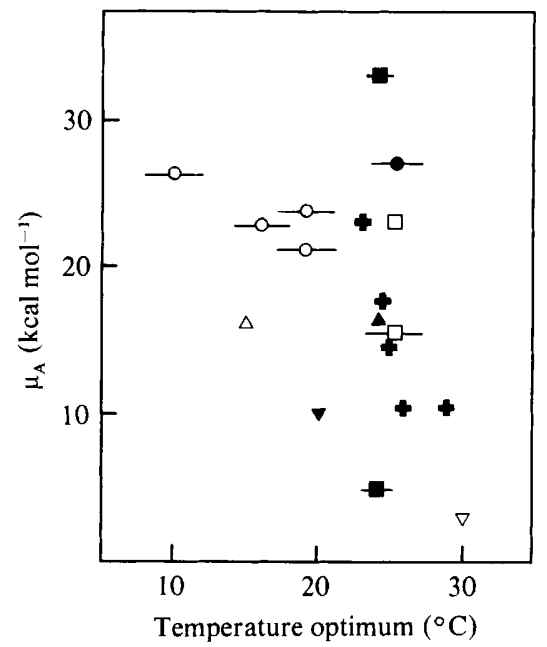

Fig. 1

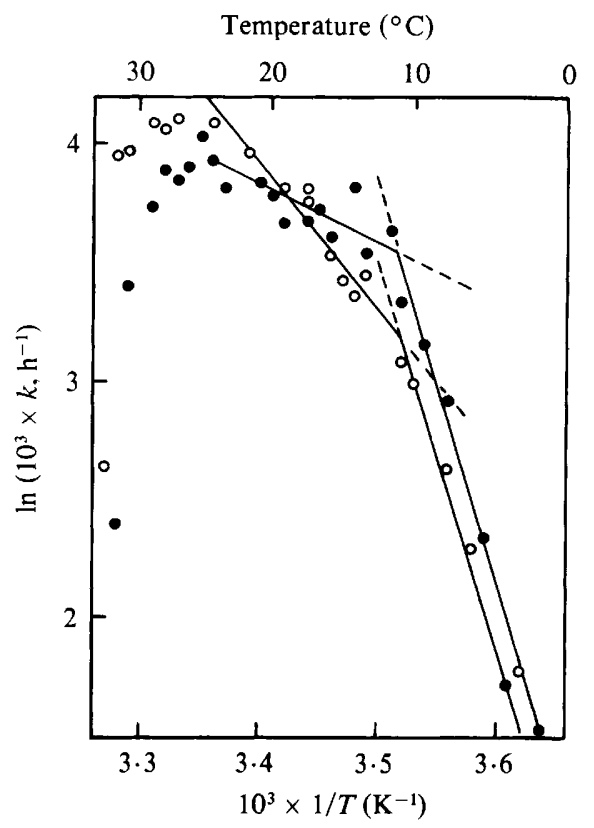

Fig. 2

Fig. 1. The $\mu_{\mathrm{A}}$ values of psychrophilic and psychrotrophic bacteria and ranges of optimal growth temperatures. $O$, Gram-negative rods with respiratory metabolism, isolated from Rhône Glacier, Switzerland; O, Bacillus sp., from a subalpine stream, S.W. Germany; $\square$, pseudomonads, from profundal lake sediment (1000 m, Lake Baikal, Siberia); Cytophaga johnsonae C21, from a eutrophic lake, West Germany $\left(\mu_{\mathrm{A} 1}=4.7\right.$ and $\mu_{\mathrm{A} 2}=33.3$ ); $\Delta$, Vibrio marinus MP1 (Hanus \& Morita, 1968); $\Delta, V$. marinus PS-207 (Hanus \& Morita, 1968); $\nabla$, Pseudomonas fluorescens (estimated value of $\mu_{\mathrm{A} 1}=3 \cdot 2$ ) (from Lynch et al., 1975); $\boldsymbol{\nabla}$, Micrococcus cryophilus (Tai \& Jackson, 1969); +, psychrotrophic bacteria, from Antarctic peat (Baker, 1974). Data points from the present study are marked by horizontal bars indicating the length of the temperature intervals employed during measurement of the optimal growth temperatures.

Fig. 2. Arrhenius plots for a psychrotrophic strain of Cytophaga johnsonae (C21) after growth of the inoculum at 10 or $23^{\circ} \mathrm{C}$. Data points contributing to the negative slopes in each experiment were grouped by linear regression analysis to produce two straight lines with $r^{2}$ values maximized over the entire range of suboptimal growth temperatures tested. Temperature characteristics calculated for the upper $\left(\mu_{\mathrm{A1}}\right)$ and lower $\left(\mu_{\mathrm{A} 2}\right)$ ranges of suboptimal temperatures, together with $r^{2}$ values (in parentheses) were: inoculum grown at $10^{\circ} \mathrm{C}(\mathrm{O}), \mu_{\mathrm{A} 1}=4.7(0.64), \mu_{\mathrm{A} 2}=33.3(0.98)$; inoculum grown at $23{ }^{\circ} \mathrm{C}$ (O), $\mu_{\mathrm{A} 1}=12.3(0.93), \mu_{\mathrm{A} 2}=32.0(0.85)$.

independent of the different techniques used to measure exponential growth rates (as shown for Vibrio marinus).

One of our psychrotrophic isolates (Cytophaga johnsonae C21) showed two distinct temperature characteristics (see below), although its temperature optimum was only 23-25 ${ }^{\circ} \mathrm{C}$. According to Mohr \& Krawiec (1980), such disparate Arrhenius profiles can only be expected for bacteria with growth temperature optima higher than $37^{\circ} \mathrm{C}$. Furthermore, calculations of $\mu_{\mathrm{A}}$ values based on published data of another psychrotrophic bacterium (Pseudomonas fluorescens strain E20) indicated that this was not a singular finding (Fig. 1; Lynch et al., 1975).

\section{Effect of temperature acclimation of the inoculum on temperature characteristics}

Deviations within the negative slope of Arrhenius plots have been interpreted as due to uncoupling of energy production from energy utilization (Senez, 1962; Ng, 1969). Such 
deviations may also occur as a result of insufficient temperature acclimation which should be considered as an intrinsic factor influencing growth rate measurements in a temperature gradient (Shaw, 1967; Zachariah \& Liston, 1973). Therefore, temperature-dependent exponential growth rates of Cytophaga johnsonae C21 were determined, not only after the lapse of approximately one generation time, but also by using inocula from cultures adapted to different temperatures (Fig. 2). The first negative slope for the temperature range from $24-12{ }^{\circ} \mathrm{C}$ corresponded to a temperature characteristic $\left(\mu_{\mathrm{A} 1}\right)$ of 4.7 when the cells in the inoculum were acclimated to $10^{\circ} \mathrm{C}$, whereas the temperature characteristic was 12.3 when the cells in the inoculum were acclimated to $23^{\circ} \mathrm{C}$. On the other hand, the temperature characteristics calculated from the second negative slope of the Arrhenius plots $\left(\mu_{\mathrm{A} 2}\right)$ were almost identical $\left(33.3\right.$ after $10^{\circ} \mathrm{C}$ acclimation, and 32.0 after $23^{\circ} \mathrm{C}$ acclimation). These results suggested an adaptation in the upper temperature range, rather than in the lower as described for psychrotrophic strains of Pseudomonas (Zachariah \& Liston, 1973).

\section{CONCLUSIONS}

Our data on psychrophilic and psychrotrophic bacteria deviate considerably from the observations and conclusions of Mohr \& Krawiec (1980) who referred to only three isolates with comparably low growth temperature ranges. As a measure of the activation energy for growth at suboptimal temperatures, temperature characteristics $\left(\mu_{\mathrm{A}}\right)$ describe primarily the energetic favouring of substrate-specific growth reactions, and are not necessarily linked to certain growth temperature ranges or temperature optima (Dean \& Hinshelwood, 1966; Kovacs et al., 1968; Hanus \& Morita, 1968; Reichardt, 1971; Baker, 1974; Morita, 1975). Our results show that neither the empirical relationship between optimal growth temperatures and temperature characteristics $\left(\mu_{\mathrm{A}}\right)$ nor the reported restriction of disparate Arrhenius profiles to mesophiles and thermophiles, as suggested by Mohr \& Krawiec (1980), are generally applicable phenomena.

The authors wish to thank J. H. Baker for critical reading of the manuscript.

Published technical paper no. 5987, Oregon Agricultural Experiment Station.

\section{REF E R E N C E S}

ARRHENIUS, S. (1908). Immunochemie. Ergebnisse der Physiologie 7, 480-551.

BAKER, J. H. (1974). The use of a temperature-gradient incubator to investigate the temperature characteristics of some bacteria from Antarctic peat. British Antarctic Survey Bulletin 39, 49-59.

DEAN, A. C. R. \& Hinshelwood, C. (1966). Growth, Function and Regulation in Bacterial Cells. London: Oxford University Press.

Hanus, F. J. \& Morita, R. Y. (1968). Significance of the temperature characteristic of growth. Journal of Bacteriology 95, 736-737.

INGRAHAM, J. L. (1958). Growth of psychrophilic bacteria. Journal of Bacteriology 76, 75-80.

Kovacs, E., Zukal, E. \& Mazarean, H. H. (1968). Deutung und Bestimmung der scheinbaren Aktivierungsenergie in Staphylococcus aureusKulturen. Enzymologia 34, 242-250.

LYNCH, W. H., Macleod, J. \& Franklin, M. (1975). Effect of growth temperature on the accumulation of glucose oxidation products in Pseudomonas fluorescens. Canadian Journal of Microbiology 21, 1553-1559.

Mohr, P. W. \& Krawiec, S. (1980). Temperature characteristics and Arrhenius plots for nominal psychrophiles, mesophiles and thermophiles. Journal of General Microbiology 121, 311-317.
Morita, R. Y. (1975). Psychrophilic bacteria. Bacteriological Reviews 39, 144-167.

NG, H. (1969). Effect of decreasing growth temperature on cell yield of Escherichia coli. Journal of Bacteriology 98, 232-237.

ReICHARDT, W. (1971). Oekophysiologische Untersuchungen zur Dephosphorylierung in Cyanophyceen-Kulturen. Zeitschrift für allgemeine Mikrobiologie 11, 501-524.

REICHARDT, W. (1974). Zur Oekophysiologie einiger Gewässerbakterien aus der FlavobacteriumCytophaga-Gruppe. Zentralblatt für Bakteriologie, Parasitenkunde, Infektionskrankheiten und Hygiene (Abteilung I, Originale A) 227, 85-93.

SENEZ, J. C. (1962). Some considerations on the energetics of bacterial growth. Bacteriological Reviews 26, 95-107.

SHAw, M. K. (1967). Effect of abrupt temperature shift on the growth of mesophilic and psychrophilic yeasts. Journal of Bacteriology 93, 1332-1336.

TAI, P. C. \& JACKSON, H. (1969). Growth and respiration of an obligate psychrophile, Micrococcus cryophilus, and its mesophilic mutants. Canadian Journal of Microbiology 15, 1151-1155.

ZACHARIAH, P. \& Liston, J. (1973). Temperature adaptability of psychrotrophic Pseudomonas. Applied Microbiology 26, 437-438. 